\title{
Gill Morphology in Two Bottom Feeder Mediterranean Sea Fishes: Grey Gurnard Fish (Eutrigla gurnardus, Linnaeus, 1758) and Striped Red Mullet Fish (Mullus barbatus surmuletus, Linnaeus, 1758) by Scanning Electron Microscopy
}

\author{
Morfología de las Branquias en Dos Peces que se alimentan en el Fondo del Mar \\ Mediterráneo: Gurnard Grises (Eutrigla gurnardus, Linnaeus, 1758) y Salmonete Rojo \\ Rayado (Mullus barbatus surmuletus, Linnaeus, 1758) por Microscopía Electrónica de Barrido
}

Mohamed M. A. Abumandour ${ }^{1}$ \& Neveen E. R. El-Bakary ${ }^{2}$

ABUMANDOUR, M. M. A. \& EL-BAKARY, N. E. R. Gill morphology in two bottom feeder Mediterranean sea fishes: Grey Gurnard fish (Eutrigla gurnardus, Linnaeus, 1758) and striped red mullet fish (Mullus barbatus surmuletus, Linnaeus, 1758) by scanning electron microscopy. Int. J.Morphol., 35(1):77-84, 2017.

SUMMARY: The purpose of the current investigation was to describe the gill morphology of two bottom feeders Mediterranean Sea fishes: Striped red mullet fish (M. surmuletus) and grey gurnard fish (E. gurnardus) that showed the same feeding habits. The gill system of the grey gurnard consisted of four pairs of gill arches while consisted of three pairs of gill arches in the striped red mullet. Our study focused on the scanning electron microscopical (SEM) features of the gills, where some differences in the gill arches and gill rakers surface in both species were observed. Our results marked that there was an interbranchial septum carrying a four transverse elevated crest in grey gurnard while in striped red mullet carrying a median longitudinal elevated crest. There are some similar structure on the gill arch of two fishes as; no angle between a ceratobranchial part and epibranchial part and also the gill arch has a region of many longitudinal microridges demarcated the region between gill rakers and gill filaments. By SEM, in striped red mullet, the smooth surface of gill arch and gill rakers was characterized by the presence of high number of taste buds. By SEM in grey gurnard, gill raker appeared as a round short projected body with high number of curved apex spines. Furthermore, in striped red mullet, gill raker appeared as short projected body with high number of rod-like spines. Gill filaments were long at middle and short at extremities of gill arch in both species. filament.

KEY WORDS: Grey gurnard fish; Striped red mullet fish; Scanning electron microscopy; Gill raker; Gill arch; Gill

\section{INTRODUCTION}

The grey gurnard of species E. gurnardus was belonged to Triglidae family and Genus Eutrigla and considered one of the bottom-feeding scorpaeniform fish. This species was present in the eastern Atlantic Ocean, Mediterranean Sea and Black Sea. This species is the only known member of its genus. This species is usually found on muddy or sandy seabeds or in areas of mixed sediment and rock. It is most frequently encountered at depths between 20-50 m although it is known to occur from 10-200 m. Its diet consists of bottom-living crustaceans and small fish.

The striped red mullet or surmullet of species $M$. surmuletus belongs to a species of goatfish of family Mullidae and Genus Mullus. This species was found in the Mediterranean Sea, eastern North Atlantic Ocean, and the Black Sea. The striped red mullet is one of the tireless bottom feeders living on worms, crustaceans, molluscs and other small invertebrates.

The study of the morphology of the different types of fish is a more interesting research point for many researchers, as there are many attractive points in the gill as noted in a number of published articles (Hughes \& Morgan, 1973; Laurent \& Hebibi 1989; Goss et al., 1992; Balm et al., 1996; Zayed \& Mohamed, 2004; Saliu \& Olonire, 2008; Monteiro et al., 2011; Alsafy, 2013; Abumandour \& Gewaily, 2016).

\footnotetext{
${ }^{1}$ Department of Anatomy and Embryology, Faculty of Veterinary Medicine, Alexandria University, Egypt.

${ }^{2}$ Department of Zoology, Faculty of Science, Damietta University, Egypt.
} 

fish (Mullus barbatus surmuletus, Linnaeus, 1758) by scanning electron microscopy. Int. J.Morphol., 35(1):77-84, 2017.

The gills are related to several important vital functions of all fishes; the first and important function is that the gills are considered the main respiratory sites of gas exchange in all fishes (Moyle \& Cech, 1996), while the secondary function is related to feeding habits where the organization of gill filaments and rakers were reflected to the feeding habits of the fish (Fernandes et al., 2003; Kumari et al., 2009), in which the organization and size of the gill rakers played a role in controlling the size of food particles eaten. Fish with many long rakers are filter feeders, whereas species with few short rakers are omnivores and carnivores (Moodie, 1985; Mummert \& Drenner, 1986). So, the present investigation was focus on the comparative morphological features of the gills of grey gurnard fish (E. gurnardus) and striped red mullet fish (M. surmuletus) by gross anatomy, scanning electron microscopy.

\section{MATERIAL AND METHOD}

Sample. Ten mature fishes of grey gurnard (E. gurnardus) and striped red mullet (M. surmuletus), their weights ranged 40-50 $\mathrm{g}$ and their length measured from $25-35 \mathrm{~cm}$; the fishes were collected after catch from the Mediterranean Sea, in Damietta city, Damietta Governorate, Egypt and transported in plastic aquariums to our lab within $2 \mathrm{~h}$ to carry out the gross morphology and scanning electron microscopes comparison studies on their gills.

For gross morphological study. Seven mature fishes from each fish species were used to clarify the gross morphological features. The opercular cavity was opened and the gill and associated accessory respiratory organs were examined in
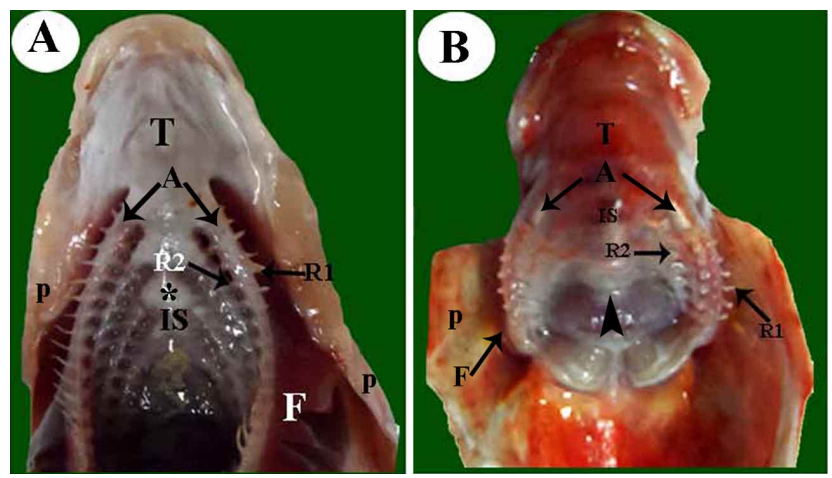

Fig. 1. Gross anatomical Photographs of the gills in; grey gurnard (E. gurnardus) view (A) and striped red mullet (M. surmuletus) View (B). showing; tongue (T), gill arch (A), operculum (P), gill filament $(\mathrm{F})$, lateral long raker (R1), medial short raker (R2), transverse ridges at the union site between two gill arch $(*)$, median longitudinal ridge (black head arrow) at the middle of interbranchial septum (IS). situ, and all the previous parts were carefully dissected and photographed by digital camera (Cannon IXY 325, Japan). For scanning electron microscopic study. Three fishes were used. Small specimens from gills of both fishes were taken immediately after catching. The samples were fixed in a glutaraldehyde $3 \%$ solution at $4{ }^{\circ} \mathrm{C}$ for 24 hours then dehydrated through a graded series of acetone. After that, the specimens were post-fixed in osmium tetroxide $1 \%$ in a phosphate buffer for 2 hours. The samples were subsequently dehydrated in ascending grades of ethanol followed bycritical point drying in carbon dioxide. Subsequently, the samples were coated with gold and examined with JEOL JSM 5300 scanning electron microscope operating at $15 \mathrm{kV}$, Faculty of Science Alexandria University.

\section{RESULTS}

The gill system of the grey gurnard and striped red mullet was confined within two interconnected gill chambers. The gill chambers are bounded ventrally by the mandible, dorsally by the roof of the oropharyngeal cavity, and laterally by operculum (gill covering) while medially they appear continuous with each other. The gill system of the grey consisted of four pairs of gill arches, which were termed from the lateral to medial as first, second, third and fourth (Fig. 1A), while the gill system of the striped red mullet was consisted of three pairs of gill arches, which were termed from the lateral to medial as first, second and third (Fig. 1B). Each gill arch is general somewhat cresentricshape carrying gill rakers on its concave border and gill filaments on its convex border. The opercular cavity was closed laterally by the operculum leaving a wide ventrolateral opening in two species fishes.

Gill arch. Grossly, the gill arch has a cresentic-shape and oblique rostroventrally, carrying gill rakers on its concave border and gill filaments on its convex border (Fig. 1). Each gill arch has two extremities; rostral and caudal. The rostral extremities of gill arches are united forming a wide interbranchial septum between the contra-lateral gills (Fig. 1). The interbranchial septum appeared quadrilateral narrow and carrying a four transverse elevated crest in grey gurnard (Fig. 1A) while in the striped red mullet the interbranchial septum appeared semilunar with a median longitudinal elevated crest (Fig. 1). They are connected with each other and attached to the dorsolateral wall of pharynx. Each gill arch is devoid from the angle between a ceratobranchial part and epibranchial part, so it is difficult to recognize the ceratobranchial part from epibranchial part. The gill arches are connected with each other rostrally and caudally (Fig. 1). 

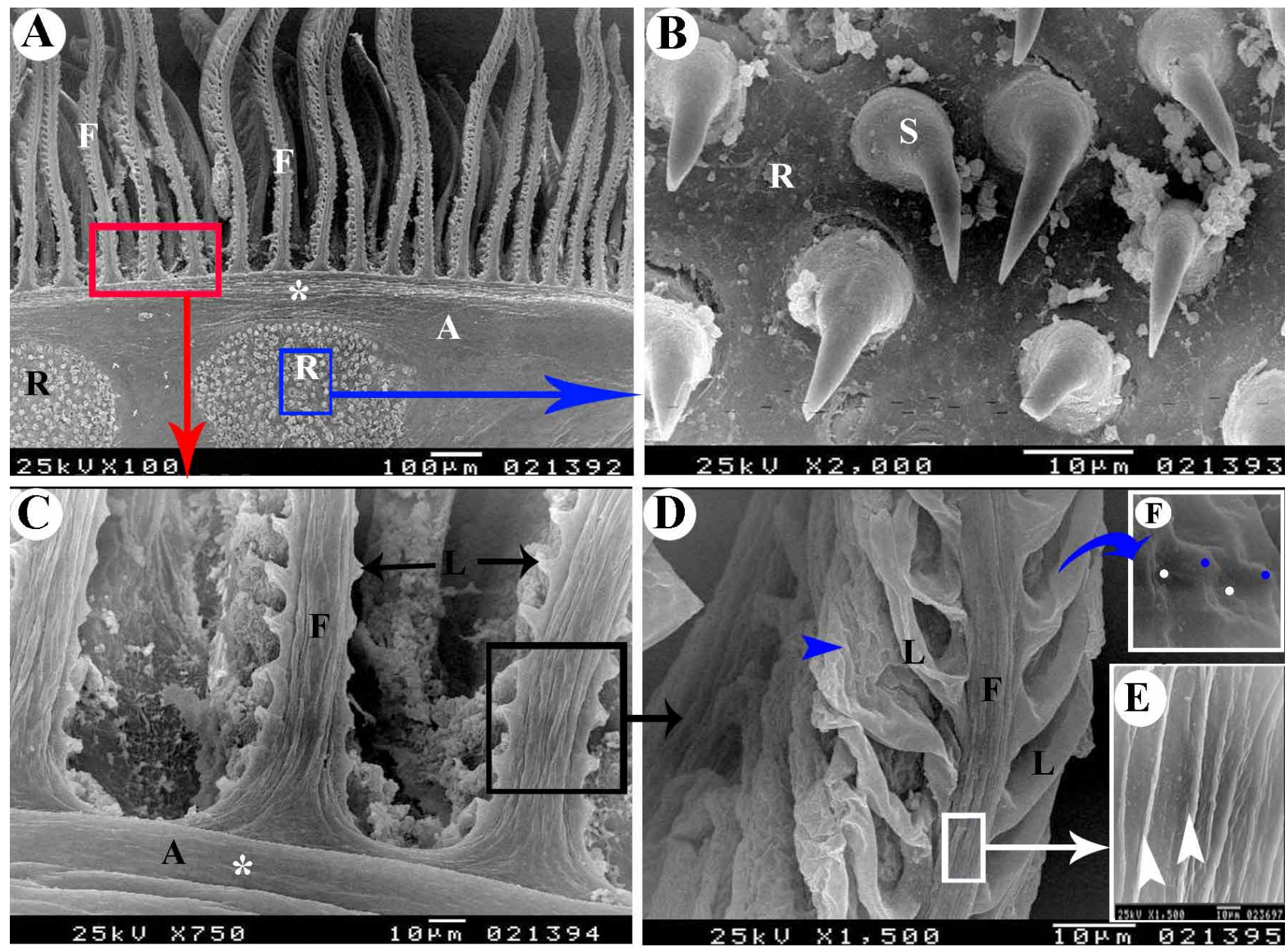

Fig. 2.Scanning electron micrographs (View A to F) of gill in the grey gurnard (E. gurnardus). View (A) Showing the gill arch (A), the region (white *) between the gill rakers $(\mathrm{R})$ and the beginning of the gill filaments $(\mathrm{F})$. View $(\mathrm{B})$ represents the high magnification of the blue marked area in View (A) to clarify the curved apex spine $(\mathrm{S})$ on the surface of the gill raker (R). View (C) represents the high magnification of the red marked area in View (A) to clarify the region (white $*$ ) on the surface of the gill arch (A) between the gill rakers $(\mathrm{R})$ and the beginning of the primary gill filaments $(\mathrm{F})$, secondary lamellae(L). View (D) represents the high magnification of the black marked area in View (C) to clarify the primary gill filaments (F), secondary lamellae (L). View (E) represents the high magnification of the white marked area of the surface of the primary gill filament in View (C) to clarify the surface of primary gill filaments (F) which characterized by the presence of many longitudinal ridges (white arrowheads). View (F) represents the high magnification of the surface of secondary lamellae (L) which characterized by the presence of many elevated area called the polyhedral cells (blue dotes) and many depressed parts (white dot).

By scanning electron microscope in both species, the surface of gill arch is characterized by the presence of gill rakers with multiple small spines on the gill raker surface (Figs. 2A and B) in grey gurnard and (Figs 3A and 2B) in the striped red mullet. In both species, all surfaces of the gill arch appeared to be characterized by the smooth surface except a region of many longitudinal microridges demarcated the region between the gill rakers and the area of origin of gill filaments (Figs. 2A and C) (Fig. 3A), in addition to the previous in the striped red mullet was characteristic by the presence of high number of the taste buds on the smooth surface of the gill arch and the gill rakers (Figs. 3A and B).
Gill rakers. Macroscopically, the gill rakers are located on the concave internal side of the gill arches. Each gill arch was bearing two rows of rakers; long lateral and medial short rakers on the first gill arch while the rest gill arches show short lateral and medial gill rakers in grey gurnard (Fig.1A) while in the striped red mullet, all the three gill arches were carrying short lateral and medial gill rakers (Fig. 1B). The rakers of adjacent gill arches are interdigitated with each other (Fig. 1). The average numbers of the gill rakers appeared slightly variable in the different gills; in grey gurnard, the number of rakers on the lateral rows of the $1^{\text {st }}, 2^{\text {nd }}, 3^{\text {rd }}$ and $4^{\text {th }}$ gill arches was 16 and 14 and 12 rakers respectively, while 
on the medial rows were 17,14 and 12 respectively. Furthermore, in the striped red mullet, the number of rakers on the lateral rows of the $1^{\text {st }}, 2^{\text {nd }}, 3^{\text {rd }}$ and $4^{\text {th }}$ gill arches were 11 and 9 and 8 rakers respectively, while on the medial rows were 12,10 and 11 respectively.

By SEM in grey gurnard, the gill rakers appeared as round short projected bodies with high number of spines giving the appearance of round dotted area (Fig. 2A), moreover with high magnification of gill rakers, the curved apex of these spines have various directions (Fig. 2B). Furthermore, in the striped red mullet, the gill rakers appeared as short projected bodies with high number of spines directing toward the concave internal side of the gill arches (Fig. 3A), moreover with high magnification of gill rakers, the rod-like spines were surrounded by many taste buds (Fig. 3A).

Gill filaments. Our macroscopic investigations observed that, the gill filaments are branched from the convex external surface of the gill arch in a perpendicular manner, pointing toward the gill cavity. Each gill filament is called a holobranch which in turn is formed of two well-developed compactly adherent hemibranches (lateral and medial hemibranches) (Figs 1A and B). The length of gill filaments has a little variation along the whole length of gill arches, where, the gill filaments appeared longer in the middle portion of the arch while being shorter toward the extremities.
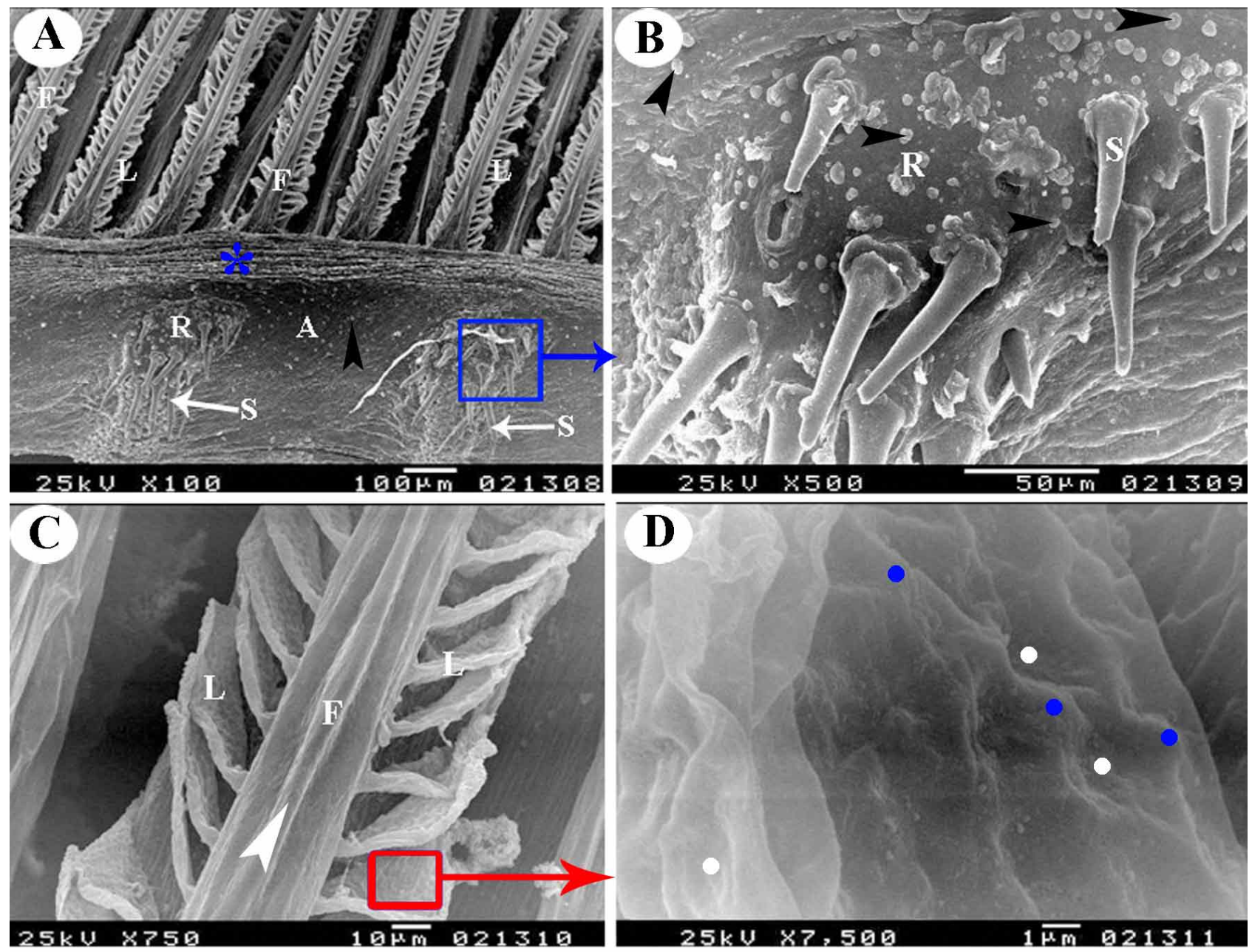

Fig. 3.: Scanning electron micrographs (A-D) of gill of the striped red mullet (M. surmuletus). View (A) Showing the region (blue *) between the gill rakers $(\mathrm{R})$ and the beginning of the gill filaments $(\mathrm{F})$, secondary lamellae $(\mathrm{L})$, spines $(\mathrm{S})$ on the surface of the gill raker (R), many taste buds (black head arrow) on the surface of the gill arch (A) and gill raker (R). View (B) represents the high magnification of the blue marked area in View (A) to clarify the rod-like spines (S) and many taste buds (black head arrow) on the surface of the gill raker $(\mathrm{R})$. View $(\mathrm{C})$ represents the high magnification of the gill filament $(\mathrm{F})$ to clarify the secondary lamellae (L) and the presence of only one median longitudinal ridge (white arrowhead). View (D) represents the high magnification of the red marked area of the surface of the secondary lamellae in View (C) to clarify the surface of secondary lamellae which characterized by the presence of many elevated area called the polyhedral cells (blue dot) and many depressed parts (white dot). 
ABUMANDOUR, M. M. A. \& EL-BAKARY, N. E. R. Gill morphology in two bottom feeder Mediterranean sea fishes: Grey Gurnard fish (Eutrigla gurnardus, Linnaeus, 1758) and striped red mullet fish (Mullus barbatus surmuletus, Linnaeus, 1758) by scanning electron microscopy. Int. J.Morphol., 35(1):77-84, 2017.

By SEM, the gill filaments are considered to be the primary lamellae (Figs. 2A and C, 3A and C), from which a very small pointed secondary lamellae in the grey gurnard and a leaf-like secondary lamellae in the striped red mullet were branched from both sides and originated at the right angles to the longitudinal axis of the filaments (Figs. 2C and D, 3A and C). The secondary lamellae are lying parallel to each other. Moreover, with high magnification in the grey gurnard, these small pointed secondary lamellae appeared as a leaf-like projections from both sides of the primary lamellae and the surface of the primary lamellae appeared carrying many longitudinal rows of epithelial cells (Figs. $2 \mathrm{D}$ and $\mathrm{E})$, while the surface of the lamellae appeared to be similar in two species having the polyhedral cells (Figs. 2F and 3D) with high magnification. While with high magnification in striped red mullet, the surface of the primary lamellae appeared carrying only one longitudinal row of epithelial cells (Fig. 3C).

\section{DISCUSSION}

The present investigation represents the first morphological description of gills of this two fish species. Many studies of teleost gills have described the morphological and functional characteristics of gill epithelial cells (Carmona et al., 2004; Abumandour \& Gewaily). These cells participate in various functions, such as gas exchange, maintenance of blood acid-base balance and ionic regulation (Brown, 1992; Laurent et al., 1994a; Laurent et al., 1994b; Moron \& Fernandes, 1996; Perry, 1997; Fernandes et al., 1998; Goss et al., 1998; Sturla et al., 2001).

From the previous data, the anatomical position and shape of the gill opening is very important as it explains the physiological contradictions between fish species. The present investigation agrees with many published data that the gill chamber of most teleost fish was bound laterally by the operculum which closing the ventrolaterally opened gill opening is different in its position and mechanism of action (Eiras-Stofella \& Charvet-Almeida, 1997; Eiras-Stofella \& Charvet-Almeida, 2000; Alsafy; Elsheikh, 2013). On the other hand, the gill slits are a characteristic feature to cartilaginous fish such as sharks and rays, in which they are characterized by the absence of a single outer gill cover and replaced by individual openings to gills (Gerhart et al., 2005).

Our study revealed that the wide ventrolaterally gill opening covered by the operculum was reported in most teleost fish species (Eiras-Stofella \& Charvet-Almeida, 1997; EirasStofella \& Charvet-Almeida, 2000; Alsafy; Elsheikh), in contrast, Zayed \& Mohamed reported that the catfish has a small gill opening. This variation about the size of the gill opening was explained by Norman \& Greenwood (1963) which reported that fishes with a wide external gill opening die more rapidly than those which have a small opening meanwhile, in the puffer fisch (Abumandour \& Gewaily) reported that the slit-like gill opening was characterized by the absence of gill cover which located cranial to the base of the pectoral fin.

There are great variations in the number of gill arches between the different fish species; in the present study there are three pairs of gills in the striped red mullet, as noted in the puffer fisch (Abumandour \& Gewaily), however, the four pairs of gills is the common number in most teleost fishes as in the present investigation in the grey gurnard (Hughes \& Grimstone, 1965; Hughes \& Morgan; Hossler et al., 1985; Eiras-Stofella et al., 2001; Eiras-Stofella \& Fank-de-Carvalho, 2002; Zayed \& Mohamed; Cinar et al., 2009; Díaz et al., 2009; Kumari et al., 2009; Kumari et al., 2012; Alsafy; Elsheikh). However, there are five pairs of gills, but the fifth pair is ill developed and devoid from any gill filaments as noted in catfish (Zayed \& Mohamed; Kumari et al., 2005; Elsheikh), in contrast, in Senegal sole (Arellano et al., 2004) reported that the fifth pair is well-developed and contains gill filaments. Moreover, the cartilaginous fish have five to seven pairs of gills, and primitive jawless fish have seven pairs of gills (Romer, 1949).

The present study reported that, the rostral extremities of gill arches were united forming a wide interbranchial septum between the contra-lateral gills as reported by Zayed \& Mohamed and Alsafy. Furthermore, the current study showed that the interbranchial septum appeared quadrilateral narrow and carrying a four transverse elevated crest in grey gurnard while in the striped red mullet the interbranchial septum appeared semilunar with a longitudinal elevated crest. Furthermore, the present SEM study revealed that, all surfaces of the gill arch appeared smooth, except the area of the many transverse microridges between the region between the gill rakers and the area of origin of the gill filaments (Abumandour \& Gewaily).

The present investigation observed that there is no angle between the two parts of the gill arch; epibranchials and ceratobranchials, the similar observation was observed by Hossler et al. (1979) and Eiras-Stofella et al. However, the most common in all teleost fish is the presence of a clear angle as noted in many literatures (Eiras-Stofella \& CharvetAlmeida, 1997; Eiras-Stofella \& Charvet-Almeida, 1998, 2000; Kumari et al., 2005; Alsafy).

There is a close relation between the morphologic appearance of the gill rakers and the feeding behavior as the 
gill rakers are shown to have a lead role in determining the size of food particles eaten by fishes, in which fish with numerous elongated rakers realize sufficient filter feeding, whereas with few short rakers are known as omnivorous and carnivorous fishes (Hyatt, 1979; Moodie; Ojha et al., 1987; Ghosh et al., 1988; Eiras-Stofella et al.; Liston, 2005; Salman et al., 2005). Liston and Salman et al. reported that, the rakers act as a barrier to water flow rather than as a sieve, in which they direct the water toward the roof of the oral cavity where the food particles were trapped by their mucous covering before being ingested.

The appearance of gill rakers and the method of their organization on the gill arch showed wide variation between different fish types. The current SEM findings in grey gurnard indicated that, the gill rakers appeared as round short projected bodies with multiple curved apex spines giving the appearance of dotted area of the gill rakers while in the striped red mullet, the gill rakers appeared as short projected bodies with multiple rod-like spines directing toward the concave internal side of the gill arches and surrounded by many taste buds. In the present study, there are only two rows of gill rakers; one laterally and other medially as noted in many fishes species (Hossler et al., 1985; Abuzinadah, 1995; Zayed \& Mohamed; Salman et al.; Díaz et al.; Alsafy; Elsheikh), but there are some fishes having three rows of gill rakers as reported in catfish (Zayed \& Mohamed) and in Clarias gariepinus (Elsheikh). Abumandour \& Gewaily in puffer fish recoreded that there are three rows of gill rakers surrounded by spines on each gill arch.

The inter-raker spaces between adjacent gill rakers is considered as an important factor that determine the size of the food particles to be swallowed, this factor is related to the feeding behavior of fish as the minimum spacing between the gill rakers determines the minimum size of the prey that can be eaten (Magnuson \& Heitz, 1971; O'Brien, 1987). There are two types of fish according to inter-raker space; the first type is fishes with a narrow inter-raker spaces, which adapted to small sized food items as in Indian major carp (Kumari et al., 2009) and in Mugil curema, M. liza, and M. platanus (Eiras-Stofella et al.). The second type is a wide inter-raker spaces fishes, which adapted to large sized food items as in carnivorous, piscivorous, crustacean-feeder fishes as in; Oreochromis niloticus (Elsheikh) and in Gahash Lethrinus mahsena (Salman et al.), in addition to the present study. However, in some carnivorous species, there are narrow inter-raker spaces as in; Gymnoclytia unicolor, Caranx sexfasciatus (Abuzinadah).

Our scanning results in the striped red mullet clarified the presence of many taste buds on the surface of the gill arch and gill rakers, similar to other authors (Ghosh et al.;
Kumari et al., 2005; Díaz et al.) but absent in the present study in grey gurnard. The presence of taste buds in the gills of all fishes was related to their role in participation in tasting process at the pharyngeal region, in which the taste buds are the sense organs of the gustatory system of fish resemble that present in other vertebrates (Kasumyan, 1997; Fishelson et al., 2004).

In the present study, our results demonstrated presence of the many longitudinal parallel ridges covering the surface of the primary gill filaments in the grey gurnard while there is only one longitudinal ridge in the striped red mullet. The presence of these longitudinal ridges were suggested to have a functional role to increase the surface area to trap, convening and distribution of the mucus, and providing reserve surface areas for stretching. Kumari et al. (2005) proposed to the functional roles of this microridges to enhance the mechanical flexibility and to give greater firmness to the surface of gill arches and rakers. Although the presence of microridges may form intricate patterns in several other fishes species (Hossler et al., 1985; Ojha et al.; Eiras-Stofella \& Charvet-Almeida, 1997; Eiras-Stofella et al.; Kumari et al., 2005; Díaz et al.). However, the present study observed that the gill arch surface was smooth.

Our results revealed that the length of gill filaments has a little variation along the whole length of gill arches, where, the gill filaments appeared longer in the middle and were shorter toward the extremities as mentioned by Díaz et al., in Odontesthes argentinensis. Moreover, in freshwater fish Prochilodus scrofa Steindachner and in seawater Eugerres brasilianus, the gill filaments are shorter on both extremities of gill arch and in the strong curvature angle region (Eiras-Stofella \& Charvet-Almeida, 1998, 2000), however, Kumari et al., (2012) in catfish and Carp reported that, the length of the gill filaments is shorter on one side than on the other corresponding side of the gill arch.

The results of scanning microscopy of the present study are in conformity with the findings of Kudo \& Kimura (1984) and Evans et al., (2005) that, the secondary gill filaments were originated at the right angles to the long axis of the primary gill filaments and the secondary lamellae were lying parallel to each other. The present SEM studies revealed that there are some differences in the appearance of the gill filaments, in which the secondary filaments appear as small pointed lamellae in the grey gurnard and leaf-like secondary lamellae in the striped red mullet.

CONCLUSION. We concluded that although the two fishes belonged to the bottom feeder Mediterranean Sea fishes and shared the same marine living and feeding habits, 
our SEM investigations noted some characteristic significant difference features in the shape, arrangement and number of gill arches, filaments and rakers; the difference also included the surface appearance of the interbranchial septum. Many taste buds were observed on the gill arches and rakers of the striped red mullet. In both species, the gill rakers were characterized by the presence of the spines.

ABUMANDOUR, M. M. A. \& EL-BAKARY, N. E. R. Morfología de las branquias de dos peces que se alimentan en el fondo del mar Mediterráneo: Gurnard grises (Eutrigla gurnardus, Linnaeus, 1758) y salmonete rojo rayado (Mullus barbatus surmuletus, Linnaeus, 1758) por microscopía electrónica de barrido. Int. J.Morphol., 35(1):77-84, 2017.

RESUMEN: El propósito de este trabajo fue describir la morfología de las branquias de dos peces que se alimentan en el fondo del mar Mediterráneo: Gurnard grises (E. gurnardus) y salmonete rojo rayado (M. surmuletus) los cuales mostraron los mismos hábitos alimenticios. El sistema de branquias del E. gurnardus gris consiste en cuatro pares de arcos branquiales, mientras que en el salmonete rayado son tres pares. El estudio se centró en la observación de las características de las branquias por microscopía electrónica de barrido (MEB), donde se visualizaron algunas diferencias en ambas especies tanto en los arcos branquiales, como en la superficie de las ramas branquiales. Nuestros resultados marcaron la presencia de un septum interbranchial que presentaba cuatro crestas elevadas a nivel transversal en el E. gurnardus gris, mientras que el salmonete rayado presentaba una cresta elevada mediana longitudinal. Hay una estructura similar en el arco branquial de los dos tipos de peces, pero no hay ángulo entre una parte ceratobranquial y la parte epibranquial. Además, el arco branquial tiene una región de muchas microrredes longitudinales que delimitan la región entre las ramas branquiales y los filamentos branquiales. Por MEB, en el salmonete rayado, la superficie lisa del arco branquial y el de las ramas branquiales se caracterizaron por la presencia de un alto número de papilas gustativas. Por MEB en E. gurnardus gris, las branquias aparecieron como un cuerpo corto proyectado con un alto número de espinas de vértice curvo. Además, en el salmonete rojo rayado, el rastrillo de las branquias apareció como un cuerpo corto proyectado con un alto número de espinas tipo bastón. En ambas especies los filamentos branquiales eran largos en el centro y cortos en los extremos del arco branquial.

PALABRAS CLAVE: Pez gurnardus gris; Salmonete rojo rayado; Microscopía electrónica de barrido; Branquias; Arco branquial; Filamento branquial.

\section{REFERENCES}

Abumandour, M. M. \& Gewaily, M. S. Morphological studies on the gills of puffer fish (Lagocephalus sceleratus, Gmelin, 1789). Int. J. Morphol., 34(3):817-29, 2016.

Abuzinadah, O. A. Gill raker morphology in some Red Sea fishes of different feeding preferences. J. K. A. U. Mar. Sci., 6:93-122, 1995.

Alsafy, M. A. Gill morphology in two Mediterranean Sea fishes of similar feeding preferences: sea bream (Sparus aurata L) and sea bass (Dicentrarchus labrax). Vet. Res. Commun., 37(2):163-70, 2013.

Arellano, J. M.; Storch, V. \& Sarasquete, C. Ultrastructural and histochemical study on gills and skin of the Senegal sole, Solea senegalensis. J. Appl. Ichthyol., 20(6):452-60, 2004.

Balm, P. H. M.; Carrick, T. R.; Coenen, A. J. M. \& Pottinger, T. G. Trychophrya intermedia on the gills of rainbow trout acclimating to low ambient pH. J. Fish Biol., 48(1):147-50, 1996.

Brown, P. Gill chloride cell surface-area is greater in freshwater-adapted adult sea trout (Salmo trutta, L.) than those adapted to sea water. J. Fish Biol., 40(3) :481-4, 1992.

Carmona, R.; García-Gallego, M.; Sanz, A.; Domezaín, A. \& Ostos-Garrido, M. V. Chloride cells and pavement cells in gill epithelia of Acipenser naccarii: ultrastructural modifications in seawater-acclimated specimens. J. Fish Biol., 64(2):553-66, 2004.

Cinar, K.; Aksoy, A.; Emre, Y. \& As ti, R. N. The histology and histochemical aspects of gills of the flower fish, Pseudophoxinus antalyae. Vet. Res. Commun., 33(5):453-60, 2009.

Díaz, A. O.; Castro, M. G.; García, A. M.; Díaz de Astarloa, J. M. \& Figueroa, D. E. Gross morphology and surface ultrastructure of the gills of Odontesthes argentinensis (Actinopterygii, Atherinopsidae) from a Southwestern Atlantic coastal lagoon. Tissue Cell, 41(3):193-8, 2009.

Eiras-Stofella, D. R. \& Charvet-Almeida, P. Gills of the freshwater fish Hypostomus commersonii Val., 1840 (Loricariidae) analyzed through electron microscopy techniques. Braz. Arch. Biol. Technol., 40:785-92, 1997. Eiras-Stofella, D. R. \& Charvet-Almeida P. Ultrastructure (SEM) of the gills of Prochilodus scrofa Steindachner (Pisces, Teleostei). Rev. Bras. Zool., 15(2):279-87, 1998

Eiras-Stofella, D. R. \& Charvet-Almeida, P. Gills scanning images of the seawater fish Eugerres brasilianus (Gerreidae). Braz. Arch. Biol. Technol., 43(4), 2000.

Eiras-Stofella, D. R.; Charvet-Almeida, P.; Fanta, E. \& Vianna, A. C. Surface ultrastructure of the gills of the mullets Mugil curema, M. liza and M. platanus (Mugilidae, Pisces). J. Morphol., 247(2):122-33, 2001.

Eiras-Stofella, D. R. \& Fank-de-Carvalho, S. M. Morphology of gills of the seawater fish Cathorops spixii (Agassiz) (Ariidae) by scanning and transmission electron microscopy. Rev. Bras. Zool., 19(4):1215-20, 2002.

Elsheikh, E. H. Scanning electron microscopic studies of gill arches and rakers in relation to feeding habits of some fresh water fishes. J. Basic Appl. Zool., 66(3):121-30, 2013.

Evans, D. H.; Piermarini, P. M. \& Choe, K. P. The multifunctional fish gill: dominant site of gas exchange, osmoregulation, acid-base regulation, and excretion of nitrogenous waste. Physiol. Rev., 85(1):97-177, 2005.

Fernandes, M. N.; Castro, F. J. \& Mazon, A. F. Scanning electron microscopy of the gill raker of the Loricariid fish, Rhinelepis strigosa. Acta Microsc., 12:511-2, 2003.

Fernandes, M. N.; Perna, S. A. \& Moron, S. E. Chloride cell apical surface changes in gill epithelia of the armoured catfish Hypostomus plecostomus during exposure to distilled water. J. Fish Biol., 52(4):8449, 1998.

Fishelson, L.; Delarea, Y. \& Zverdling, A. Taste bud form and distribution on lips and in the oropharyngeal cavity of cardinal fish species (Apogonidae, Teleostei), with remarks on their dentition. J. Morphol., 259(3):316-27, 2004. 
ABUMANDOUR, M. M. A. \& EL-BAKARY, N. E. R. Gill morphology in two bottom feeder Mediterranean sea fishes: Grey Gurnard fish (Eutrigla gurnardus, Linnaeus, 1758) and striped red mullet fish (Mullus barbatus surmuletus, Linnaeus, 1758) by scanning electron microscopy. Int. J.Morphol., 35(1):77-84, 2017.

Gerhart, J.; Lowe, C. \& Kirschner, M. Hemichordates and the origin of chordates. Curr. Opin. Genet. Dev., 15(4):461-7, 2005.

Ghosh, T. K.; Singh, O. N.; Roy, P. K. \& Datta Munshi, J. S. Morphometrics and surface ultrastructure of gill rakers of three Indian teleostean fishes. Proc. Indian Natl. Sci. Acad., B54(5):331-6, 1988.

Goss, G. G.; Laurent, P. \& Perry, S. F. Evidence for a morphological component in acid-base regulation during environmental hypercapnia in the brown bullhead (Ictalurus nebulosus). Cell Tissue Res., 268(3):539-52, 1992.

Goss, G. G.; Perry, S. F.; Fryer, J. N. \& Laurent, P. Gill morphology and acidbase regulation in freshwater fishes. Comp. Biochem. Physiol. A Mol. Integr. Physiol., 119(1):107-15, 1998.

Hossler, F. E.; Musil, G.; Karnaky, K. J. Jr. \& Epstein, F. H. Surface ultrastructure of the gill arch of the killifish, Fundulus heteroclitus, from seawater and freshwater, with special reference to the morphology of apical crypts of chloride cells. J. Morphol., 185(3):377-86, 1985.

Hossler, F. E.; Ruby, J. R. \& McIlwain, T. D. The gill arch of the mullet, Mugil cephalus. I. Surface ultrastructure. J. Exp. Zool. Part A Ecol. Genet. Physiol., 208(3):379-97, 1979.

Hughes, G. M. \& Grimstone, A. V. The fine structure of the secondary lamellae of the gills of Gadus pollachius. J. Cell Sci., s3-106:343-53, 1965.

Hughes, G. M. \& Morgan, M. The structure of fish gills in relation to their respiratory function. Biol. Rev., 48(3):419-75, 1973.

Hyatt, K. D. Feeding Strategy. Fish Physiol., 8:71-119, 1979.

Kasumyan, A. O. Gustatory reception and feeding behaviour of fish. $J$. Ichthyol., 37(1):72-86, 1997.

Kudo, S. \& Kimura, N. Scanning electron microscopic studies on bacterial gill disease in rainbow trout fingerlings. Jpn. J. Ichthyol., 30(4):393-403, 1984.

Kumari, U.; Mittal, S. \& Mittal, A. K. Surface ultrastructure of the gill filaments and the secondary lamellae of the catfish, Rita rita, and the carp, Cirrhinus mrigala. Microsc. Res. Tech., 75(4):433-40, 2012.

Kumari, U.; Yashpal, M.; Mittal, S. \& Mittal, A. K. Morphology of the pharyngeal cavity, especially the surface ultrastructure of gill arches and gill rakers in relation to the feeding ecology of the catfish Rita rita (Siluriformes, Bagridae). J. Morphol., 265(2):197-208, 2005.

Kumari, U.; Yashpal, M.; Mittal, S. \& Mittal, A. K. Surface ultrastructure of gill arches and gill rakers in relation to feeding of an Indian major carp, Cirrhinus mrigala. Tissue Cell, 41(5):318-25, 2009.

Laurent, P.; Dunel-Erb, S.; Chevalier, C. \& Lignon, J. Gill epithelial cells kinetics in a freshwater teleost, Oncorhynchus mykiss during adaptation to ion-poor water and hormonal treatments. Fish Physiol. Biochem., 13(5):353-70, 1994a.

Laurent, P.; Goss, G. G. \& Perry, S. F. Proton pumps in fish gill pavement cells? Arch. Int. Physiol. Biochim. Biophys., 102(1):77-9, 1994b.

Laurent, P. \& Hebibi, N. Gill morphometry and fish osmoregulation. Can. J. Zool., 67(12):3055-63, 1989.

Liston, J. The Plasticity of Gill Raker Characteristics in Suspension Feeders: Implications for Pachycormiformes. In: Arratia, G.; Schultze, H.-P. \& Wilson, M. V. H. (Eds.). Mesozoic Fishes 5 - Global Diversity and Evolution, Munich, Pfeil Verlag, 2005. pp.121-43.

Magnuson, J. J. \& Heitz, J. G. Gill raker apparatus and food selectivity among mackerels, tunas, and dolphins. Fish. Bull., 69(2):361-70, 1971.

Monteiro, F. M.; Dutkiewicz, S. \& Follows, M. J. Biogeographical controls on the marine nitrogen fixers. Glob. Biogeochem. Cycles, 25(2):GB2003, 2011.

Moodie, G. E. E. Gill raker variation and the feeding niche of some temperate and tropical freshwater fishes. Environ. Biol. Fish., 13(1):71-6, 1985.

Moron, S. E. \& Fernandes, M. N. Pavement cell ultrastructural differences on Hoplias malabaricus gill epithelia. J. Fish Biol., 49(2):357-62, 1996.

Moyle, P. B. \& Cech, J. J. Fishes: An Introduction to Ichthyology. 3rd ed. New Jersey, Prentice-Hall, 1996.

Mummert, J. R. \& Drenner, R. W. Effect of fish size on the filtering efficiency and selective particle ingestion of a filter-feeding clupeid. Trans. Am. Fish. Soc., 115(4):522-8, 1986.

Norman, J. R. \& Greenwood, P. H. A History of Fishes. 2nd ed. London, Benn, 1963.
O'Brien W. J. Planktivory by Freshwater Fish: Thrust and Parry in the Pelagia. In: Kerfoot, W. C. \& Sih, A. (Eds.). Predation. Direct and Indirect Effects onAquatic Communities. New Hampshire, University Press of New England, 1987. pp.3-16.

Ojha, J.; Mishra, A. K. \& Munshi, J. S. D. Interspecific variations in the surface ultrastructure of the gills of freshwater mullets. Jpn. J. Ichthyol., 33(4):388-93, 1987.

Perry, S. F. The chloride cell: structure and function in the gills of freshwater fishes. Ann. Rev. Physiol., 59:325-47, 1997.

Romer, A. S. The Vertebrate Body. Philadelphia, W. B. Saunders Co., 1949.

Saliu, J. K. \& Olonire, G. T. A comparative study of the gill anatomy of Clarias anguillaris, Chrysichthys longifilis and Synodontis membranaceus from Asa reservoir and Kainji reservoir, Nigeria. Life Sci. J., 5(1):85-7, 2008.

Salman, N. A.; AL-Mahdawi, G. J. \& Heba, H. M. Gill rakers morphology and filtering mechanism in some marine teleosts from Red Sea coasts of Yamen. Egypt J. Aquat. Res., 31:286-96, 2005.

Sturla, M.; Masini, M. A.; Prato, P.; Grattarola, C. \& Uva, B. Mitochondriarich cells in gills and skin of an African lungfish, Protopterus annectens. Cell Tissue Res., 303(3):351-8, 2001.

Zayed, A. E. \& Mohamed, S. A. Morphological study on the gills of two species of fresh water fishes: Oreochromis niloticus and Clarias gariepinus. Ann. Anat., 186(4):295-304, 2004.

Corresponding author:

Mohamed M. A. Abumandour

Assistant Professor of Anatomy and Embryology

Alexandria University

Anatomy and Embryology Department

Faculty of Veterinary Medicine

Rashid Post Box: 22785

Edfina, Behera

EGYPT

Mobile phone. +201000322937

Fax: $\quad+20452960450$

E-Mail: m.abumandour@yahoo.com

Received: 18-05-2016

Accepted: 22-12-2016 